Article

\title{
Anti-Amyloidogenic Effects of Asarone Derivatives From Perilla frutescens Leaves Against Beta-Amyloid Aggregation and Nitric Oxide Production
}

\author{
Jae Eun Lee ${ }^{1,+, \ddagger}$, Nayeon Kim ${ }^{1, \dagger}$, Ji Yun Yeo ${ }^{1}$, Dae-Gun Seo ${ }^{1}$, Sunggun Kim ${ }^{1}$, Jae-Sun Lee ${ }^{1}$, \\ Kwang Woo Hwang ${ }^{2}$ and So-Young Park ${ }^{1, *}$ \\ 1 College of Pharmacy, Dankook University, 119 Dandae-ro, Dongnam-gu, Cheonan-si, Chungnam 31116, \\ Korea; jnlee88@korea.kr (J.E.L.); nayeon02200@gmail.com (N.K.); dankook_jiyun@naver.com (J.Y.Y.); \\ gun3691@naver.com (D.-G.S.); jejui@hanmail.net (S.K.); sailious34@naver.com (J.-S.L.) \\ 2 College of Pharmacy, Chung-Ang University, 84 Heukseok-ro, Dongjak-gu, Seoul 06974, Korea; \\ khwang@cau.ac.kr \\ * Correspondence: soypark23@dankook.ac.kr; Tel.: +82-41-550-1434; Fax: +82-41-559-7899 \\ + These authors contributed equally to this work. \\ $\ddagger$ Present address: National Agrobiodiversity Center, Rural Development Administration, \\ Jeonbuk 54874, Korea. \\ Academic Editor: Peter Koulen

Received: 14 October 2019; Accepted: 21 November 2019; Published: 25 November 2019

\begin{abstract}
Alzheimer's disease (AD) is a progressive, neurodegenerative brain disorder associated with loss of memory and cognitive function. Beta-amyloid $(\mathrm{A} \beta)$ aggregates, in particular, are known to be highly neurotoxic and lead to neurodegeneration. Therefore, blockade or reduction of $\mathrm{A} \beta$ aggregation is a promising therapeutic approach in $\mathrm{AD}$. We have previously reported an inhibitory effect of the methanol extract of Perilla frutescens (L.) Britton (Lamiaceae) and its hexane fraction on $\mathrm{A} \beta$ aggregation. Here, the hexane fraction of $P$. frutescens was subjected to diverse column chromatography based on activity-guided isolation methodology. This approach identified five asarone derivatives including 2,3-dimethoxy-5-(1E)-1-propen-1-yl-phenol (1), $\beta$-asarone (2), 3-(2,4,5-trimethoxyphenyl)-(2E)-2-propen-1-ol (3), asaronealdehyde (4), and $\alpha$-asarone (5). All five asarone derivatives efficiently reduced the aggregation of $A \beta$ and disaggregated preformed $A \beta$ aggregates in a dose-dependent manner as determined by a Thioflavin T (ThT) fluorescence assay. Furthermore, asarone derivatives protected PC12 cells from $\mathrm{A} \beta$ aggregate-induced toxicity by reducing the aggregation of $A \beta$, and significantly reduced NO production from LPS-stimulated BV2 microglial cells. Taken together, these results suggest that asarone derivatives derived from P. frutescens are neuroprotective and have the prophylactic and therapeutic potential in AD.
\end{abstract}

Keywords: Perilla frutescens; asarone derivative; Alzheimer's disease; beta-amyloid aggregation; beta-amyloid disaggregation; nitric oxide

\section{Introduction}

Alzheimer's disease (AD) is a chronic, progressive neurodegenerative brain disorder associated with declining memory and cognitive function, occurring in middle or late life [1]. The etiology of $\mathrm{AD}$ is poorly understood, many experts suggest that the disease results from a complex interplay of multiple factors rather than any one overriding cause. The predominant "amyloid cascade" hypothesis for $\mathrm{AD}$ development proposes that extracellular amyloid $\beta$-peptide $(\mathrm{A} \beta)$ deposits are fundamental to the pathology of $\mathrm{AD}[2]$.

$A \beta$ has been shown to be a major component of the senile plaques of AD patients. The amyloid precursor protein (APP) found on chromosome 21 is cleaved by proteases, $\beta$-secretase (BACE1) 
and $\gamma$-secretase to form the $A \beta$ peptide. $A \beta$ is very prone to aggregation, and this process is key to subsequent AD-related pathologies including tau phosphorylation, neurotoxicity, and clinical dementia [3,4]. Additionally, A $\beta$ peptides can stimulate glial cells to produce cytotoxic molecules such as nitric oxide (NO), reactive oxygen species (ROS), and other pro-inflammatory cytokines which significantly contribute to neuronal damage and death $[5,6]$. Therefore, blockade or reduction of $A \beta$ aggregation is a promising therapeutic approach.

Perilla frutescens (L.) Britton var. acuta Kudo is a perennial member of the Lamiaceae or mint family. It is primarily cultivated in China, Japan, India, Korea, and other Asian countries. It has been used as a traditional medicine to treat inflammatory diseases, depression, and anxiety-related disorders [7]. Many constituents have been isolated from the P. frutescens including rosmarinic acid, caffeic acid, luteolin, elemicin, and apigenin. Ethanol extracts of $P$. frutescens appeared to have strong anti-inflammatory and antioxidant effects [8]. Previous studies have explored the biological activity of specific compounds isolated from P. frutescens. Rosmarinic acid was shown to be an antioxidant with anti-allergic and anti-carcinogenic effects $[9,10]$. Luteolin was shown to have anti-inflammatory, anti-allergic, and anti-tumor effects [11,12], while apigenin alleviated depression [13].

The possible beneficial effects of $P$. frutescens compounds in AD remain poorly understood. Luteolin and rosmarinic acid derived from the methanolic extract of $P$. frutescens have been suggested to act as a $\beta$-secretase inhibitor by binding to either a $\beta$-secretase subsite or another regulatory site [14]. A previous study in our laboratory described the inhibitory activity of $P$. frutescens against $A \beta$ aggregation, in particular, the methanol extract [15]. Therefore, the purpose of this study was to isolate the active compounds from $P$. frutescens responsible for the observed inhibitory effect on A $\beta$ aggregation and neuroinflammation. A Thioflavin T (ThT) fluorescence assay was performed to determine the levels of $A \beta$ aggregation. A metabolic viability assay using the dye MTT was used to measure the inhibitory effect of isolated compounds on $A \beta$ aggregate-induced toxicity. Additionally, a nitric oxide (NO) release assay was performed to examine the anti-inflammatory effects of $P$. frutescens compounds on LPS-stimulated BV2 mouse microglial cells.

\section{Results}

\subsection{Isolation and Characterization of the Active Constituents Inhibiting A $\beta$ Aggregation}

We have previously reported the anti-amyloidogenic effects of $P$. frutescens methanol extract and its hexane fraction [15]. In order to isolate the active constituents of these extracts responsible for inhibiting $A \beta$ aggregation, the hexane fraction of $P$. frutescens was subjected to diverse column chromatographic separation using silica-gel, Sephadex LH-20, and C18 as stationary phases to isolate the active compounds based on the bioassay-guided isolation method. As a result, five asarone derivatives (Figure 1) were isolated as pure compounds including 2,3-dimethoxy-5-(1E)-1-propen-1-yl-phenol (1) [16], $\beta$-asarone (2) [17], 3-(2,4,5-trimethoxyphenyl)-(2E)-2-propen-1-ol ( $\alpha$-asaryl alcohol, 3) [18], asaronealdehyde (4) [19], and $\alpha$-asarone (5) [20]. The structures of these compounds were determined based on NMR and MS data in comparison with previously reported data. 
<smiles>C/C=C/c1cc(O)c(OC)c(OC)c1</smiles>

1<smiles>C/C=C\c1cc(OC)c(OC)cc1OC</smiles>

2<smiles>COc1cc(OC)c(OC)cc1/C=C/CO</smiles>

3<smiles>COc1cc(OC)c(OC)cc1C=O</smiles>

4<smiles>C/C=C/c1cc(OC)c(OC)cc1OC</smiles>

5

Figure 1. The chemical structures of asarone derivatives. Five asarone derivatives were isolated from P. frutescens based on activity-guided isolation methodology; 2,3-dimethoxy-5-(1E)-1-propen-1-yl-phenol (1), $\beta$-asarone (2), 3-(2,4,5-trimethoxyphenyl)-(2E)-2-propen-1-ol (3), asaronealdehyde (4), and $\alpha$-asarone (5).

\subsection{Asarone Derivatives Inhibit Aß Aggregation}

To determine the inhibition activity of each asarone derivative isolated from $P$. frutescens on $\mathrm{A} \beta$ aggregation, a ThT fluorescence assay was performed with DMSO-treated control group. As a control experiment, asarone derivatives were incubated with ThT without $\mathrm{A} \beta$ and the the fluorescence values of asarone derivatives with ThT were not significantly different from ThT only (Supplementary Figure S1). As shown in Figure 2, all five asarone compounds inhibited the aggregation of $A \beta$ in a dose-dependent manner. 2,3-Dimethoxy-5-(1E)-1-propen-1-yl-phenol (1) showed the highest activity, reducing $A \beta$ aggregation to $49.7 \%$ at a concentration of $100 \mu \mathrm{g} / \mathrm{mL}$ compared to $\mathrm{A} \beta$ alone. $\beta$-Asarone (2), 3-(2,4,5-trimethoxyphenyl)-(2E)-2-propen-1-ol (3), asaronealdehyde (4), and $\alpha$-asarone (5) were also reduced the $A \beta$ aggregation to $57.5 \%, 54.8 \%, 60.2 \%$, and $67.3 \%$, respectively, at the same concentration. These results were accompanied with the western blot analysis with native gels using anti-A $\beta(1-20)$ antibody (Supplementary Figure S2).

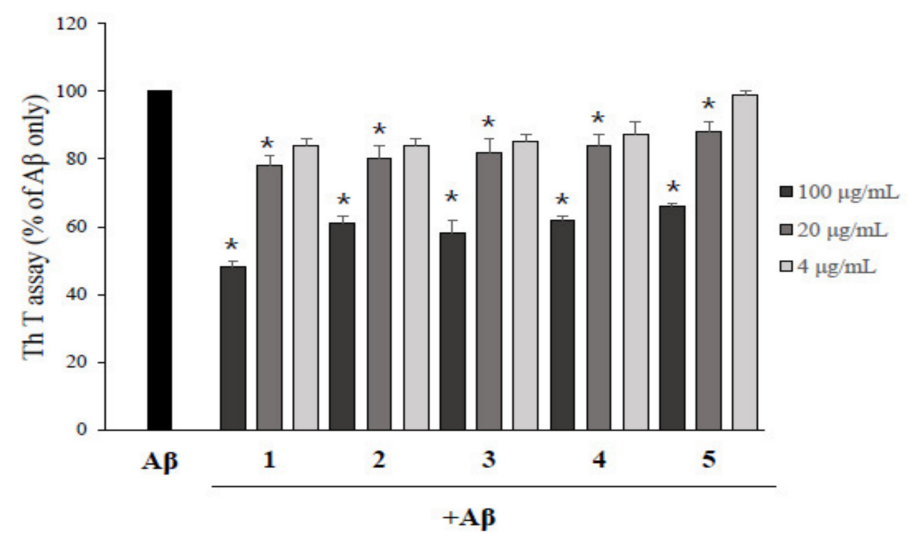

Figure 2. The inhibitory effect of asarone derivatives on $A \beta$ aggregation. The effect of asarone derivatives at 4,20 , and $100 \mu \mathrm{g} / \mathrm{mL}$ on the aggregation of $\mathrm{A} \beta$ was determined by ThT assay. $\mathrm{A} \beta$ treated with DMSO was used as a control and each experiment was repeated three times. ${ }^{*} p<0.05$ compared to the $\mathrm{A} \beta$ only-treated group. 


\subsection{Asarone Derivatives Increase the Disaggregation of Pre-Aggregated A $\beta$}

To evaluate the effects of isolated asarone derivatives on pre-formed $A \beta$ aggregates, $A \beta$ was aggregated before the addition of asarone derivatives. The degree of $A \beta$ aggregation was then determined using a ThT fluorescence assay. All five asarone derivatives efficiently reduced the levels of $A \beta$ aggregation in a dose-dependent manner (Figure 3A), suggesting that the asarone derivatives are able to disrupt $A \beta$ oligomers. 2,3-Dimethoxy-5-(1E)-1-propen-1-yl-phenol (1) and 3-(2,4,5-trimethoxyphenyl)-(2E)-2-propen-1-ol (3) were significantly effective, reducing the level of $\mathrm{A} \beta$ aggregation compared to DMSO-treated controls to $34.4 \%$ and $24.5 \%$, respectively, at a concentration of $100 \mu \mathrm{g} / \mathrm{mL}$, and $61.7 \%$ and $58.5 \%$, respectively, at $20 \mu \mathrm{g} / \mathrm{mL}$. However, $\beta$-asarone (2), asaronealdehyde (4), and $\alpha$-asarone (5) exhibited relatively moderate activity in terms of $A \beta$ disaggregation. The time-dependent effect of asarone derivatives on disaggregation of pre-aggregated $\mathrm{A} \beta$ was determined by a ThT assay (Figure 3B). Pre-aggregated A $\beta$ for $24 \mathrm{~h}$ was further incubated with asarone derivatives for 24,48 , and $72 \mathrm{~h}$. As a result, $\mathrm{A} \beta$ alone incubated group showed gradual decrease in the ThT fluorescence during the experiments, but the reduction of the ThT fluorescence was not significant. On the other hand, the ThT fluorescences of $\mathrm{A} \beta$ incubated with asarone derivatives were dramatically decreased at $24 \mathrm{~h}$. However, changes in the fluorescence levels were not significantly altered after that up to $72 \mathrm{~h}$.

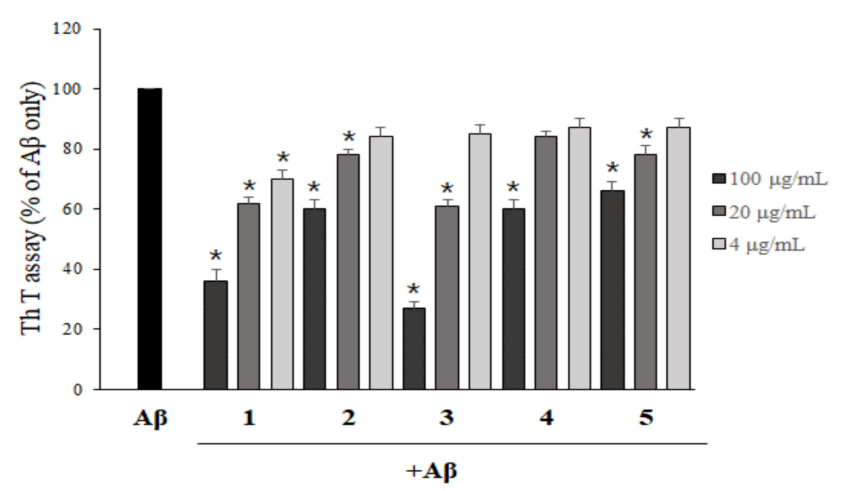

(A)

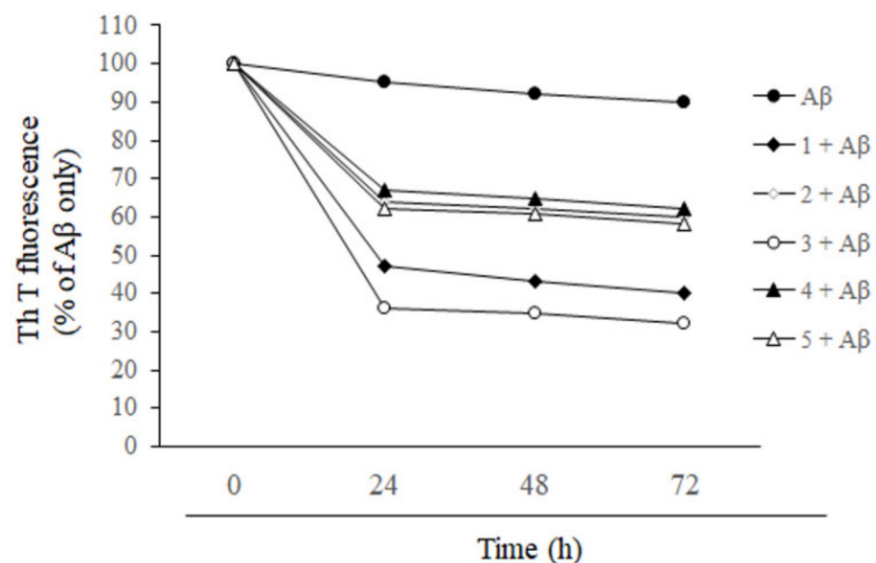

(B)

Figure 3. The effect of asarone derivatives on $A \beta$ disaggregation. (A) The $A \beta$ that had been pre-aggregated for $24 \mathrm{~h}$ was incubated with asarone derivatives for an additional $24 \mathrm{~h}$. A ThT assay was then performed to measure the levels of $A \beta$ aggregation. A $\beta$-treated with DMSO was used as a control and each experiment was repeated three times. ${ }^{*} p<0.05$ compared to the $\mathrm{A} \beta$ only-treated group. (B) Pre-aggregated A $\beta$ was incubated for 24,48 , and $72 \mathrm{~h}$ with asarone derivatives and a ThT assay was performed. 


\subsection{Asarone Derivatives Protect PC12 Cells from A -Induced Toxicity}

The possible cytotoxicity of asarone derivatives themselves on PC12 cells was determined by MTT assay. As shown in Figure 4A, $\alpha$-asarone (5) at $100 \mu \mathrm{g} / \mathrm{mL}$ significantly reduced the viability of PC12 cells, whereas no cytotoxicity was observed at 20 and $4 \mu \mathrm{g} / \mathrm{mL}$. The remaining four compounds were not cytotoxic to PC12 cells at any of the concentrations tested. Thus, the $100 \mu \mathrm{g} / \mathrm{mL}$ concentration of $\alpha$-asarone (5) was excluded from the further experiments.
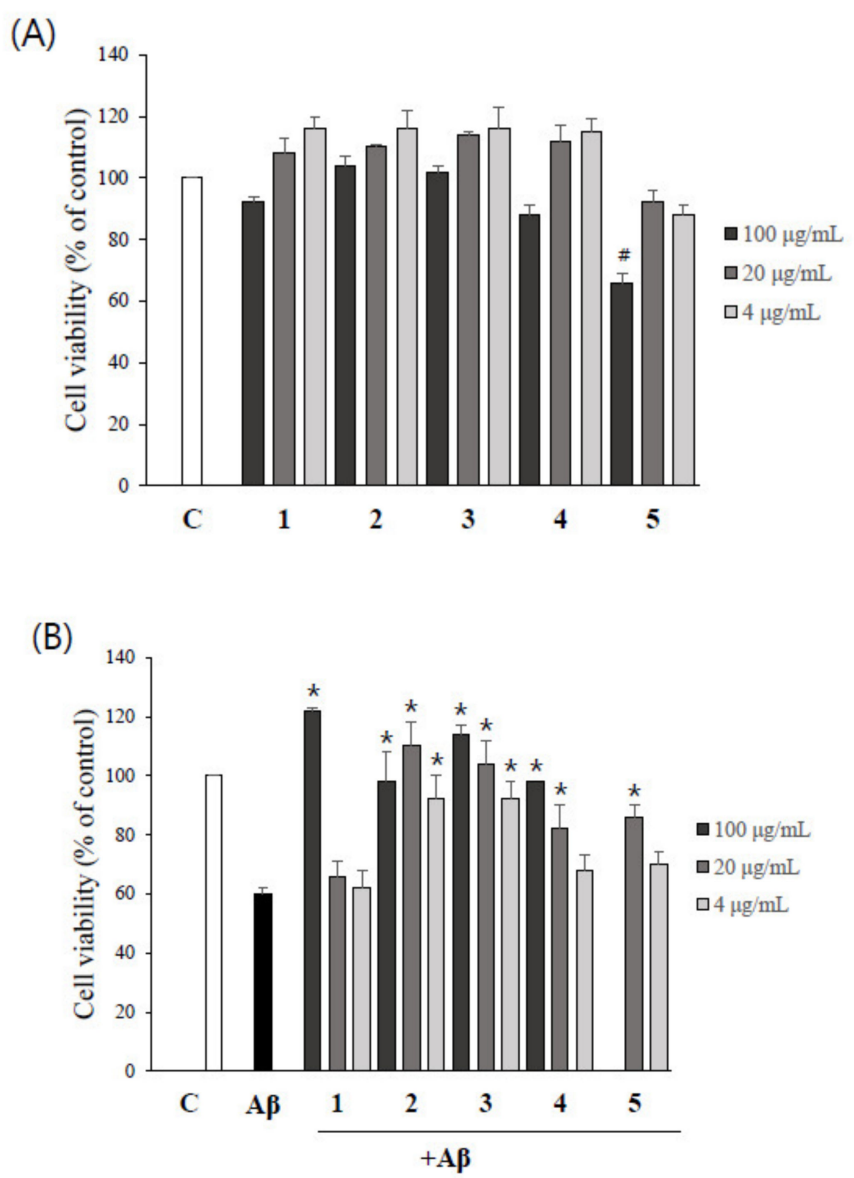

Figure 4. The protective effect of asarone derivatives against A $\beta$ toxicity itself. (A) PC12 cells were treated with asarone derivatives for $24 \mathrm{~h}$, and an MTT assay was performed to measure resulting cytotoxicity. DMSO-treated cells were used as a control. ${ }^{\#} p<0.05$, compared to DMSO-treated control group. (B) PC12 cells were pretreated with asarone derivatives for $1 \mathrm{~h}$, then incubated with A $\beta$ in order to evaluate the compounds' ability to protect the cells from $A \beta$ toxicity itself. Each experiment was repeated at least three times. ${ }^{*} p<0.05$, compared to the $\mathrm{A} \beta$ only-treated group.

To evaluate the possible protective effects of asarone derivatives against $A \beta$-induced toxicity, PC12 cells were pretreated with asarone derivatives for $1 \mathrm{~h}$, followed by the incubation with $A \beta$. Treatment of cells with $A \beta$ alone significantly reduced the viability of PC12 cells to $60.2 \%$ compared to the DMSO-treated control group. The addition of as little as $4 \mu \mathrm{g} / \mathrm{mL}$ of $\beta$-asarone (2) and 3-(2,4,5-trimethoxyphenyl)-(2E)-2-propen-1-ol (3) significantly attenuated A $\beta$-induced toxicity, resembling the level observed in the DMSO-treated control group. Higher concentrations of $100 \mu \mathrm{g} / \mathrm{mL}$ of 2,3-dimethoxy-5-(1E)-1-propen-1-yl-phenol (1) and asaronealdehyde (4), and $20 \mu \mathrm{g} / \mathrm{mL}$ of $\alpha$-asarone (5) also significantly reduced A $\beta$-induced toxicity in PC12 cells (Figure 4B). 


\subsection{The Inhibition of A A Aggregation by Asarone Derivatives Rescues PC12 Cells from A $\beta$ Toxicity}

In order to evaluate whether the inhibition of $A \beta$ aggregation by asarone derivatives shown in Figure 2 could rescue $P C 12$ cells from $A \beta$ aggregate-induced toxicity, $A \beta$ was incubated with asarone derivatives for $24 \mathrm{~h}$ before addition to cells. As shown in Figure 5, 100 and $20 \mu \mathrm{g} / \mathrm{mL}$ of $\beta$-asarone (2) significantly increased the viability of PC12 cells compared to treatment with A $\beta$ alone. In addition, 20 and $4 \mu \mathrm{g} / \mathrm{mL}$ of $\alpha$-asarone (5) efficiently protected the cells against $\mathrm{A} \beta$ aggregate-induced toxicity, resulting in cell viability of $85.7 \%$ and $76.2 \%$, respectively. 2,3-Dimethoxy-5-(1E)-1-propen-1-yl-phenol (1) and 3-(2,4,5-trimethoxyphenyl)-(2E)-2-propen-1-ol (3) at $100 \mu \mathrm{g} / \mathrm{mL}$ also significantly reduced the cytotoxicity of $A \beta$ aggregate on PC12 cells.

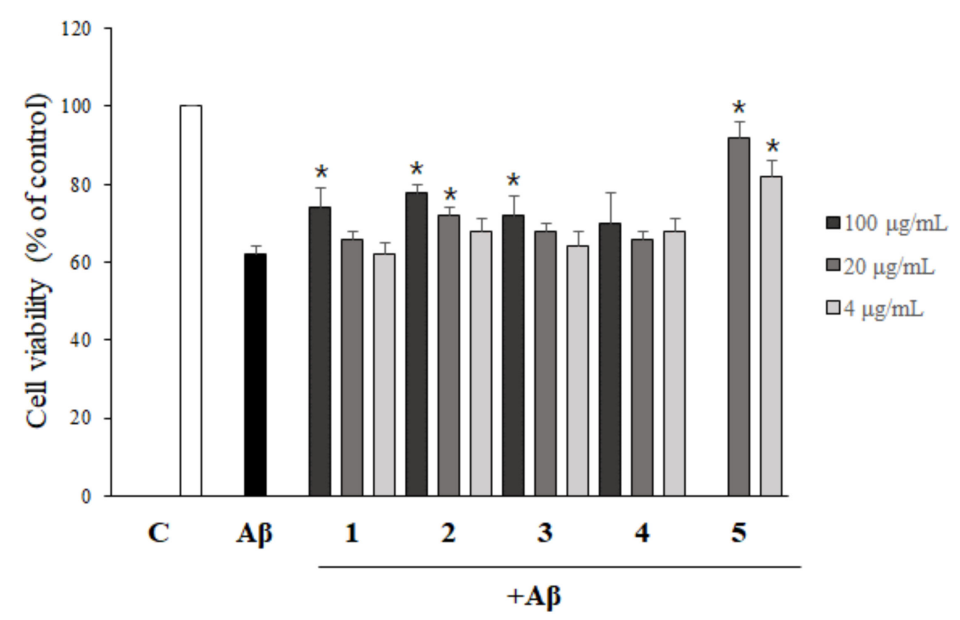

Figure 5. The neuroprotective effect of asarone derivatives on $A \beta$ aggregate-induced toxicity due to inhibition of $A \beta$ aggregation. $A \beta$ monomers were incubated with asarone derivatives for $24 \mathrm{~h}$ in order to inhibit $A \beta$ aggregation. This mixture was then added to PC12 cells for an additional $24 \mathrm{~h}$. The change of the cell viability was determined by an MTT assay. Each experiment was repeated at least three times. ${ }^{*} p<0.05$, compared to the $\mathrm{A} \beta$ only-treated group.

\subsection{Asarone Derivatives Reduce NO Production in LPS-Stimulated Microglial Cells}

To evaluate the possible cytotoxicity of asarone derivatives on BV2 microglial cells, cells were treated with various concentrations of asarone derivatives and then MTT assays were performed. With the exception of 3-(2,4,5-trimethoxyphenyl)-(2E)-2-propen-1-ol (3), no compounds had an effect on the viability of BV2 cells within the concentrations tested (up to $20 \mu \mathrm{g} / \mathrm{mL}$ ) (Figure 6A). 3-(2,4,5-Trimethoxyphenyl)-(2E)-2-propen-1-ol (3) was excluded from the following study.

We then measured the effect of asarone derivatives on LPS-induced NO production by BV2 cells. All the compounds significantly reduced LPS-stimulated NO production in a dose-dependent manner (Figure 6B). 2,3-Dimethoxy-5-(1E)-1-propen-1-yl-phenol (1), $\beta$-asarone (2) and $\alpha$-asarone (5) at $5 \mu \mathrm{g} / \mathrm{mL}$ decreased NO production to approximately half the level observed in the LPS-treated group. $20 \mu \mathrm{g} / \mathrm{mL}$ of 2,3-Dimethoxy-5-(1E)-1-propen-1-yl-phenol (1) and $\beta$-asarone (2) were particularly effective, reducing NO production to $16.3 \%$ and $4.9 \%$, respectively, compared to LPS alone. 
(A)

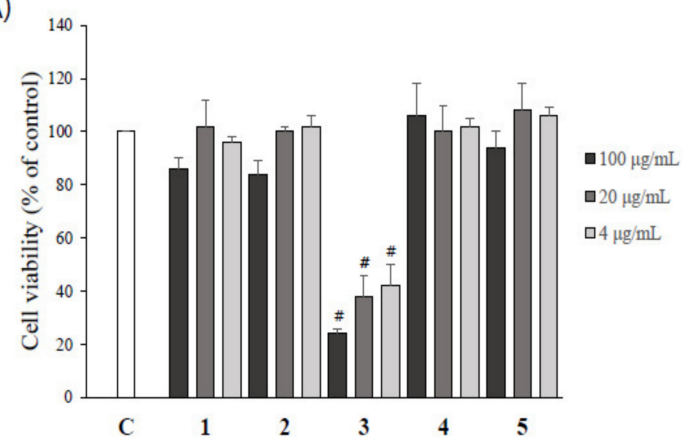

(B)

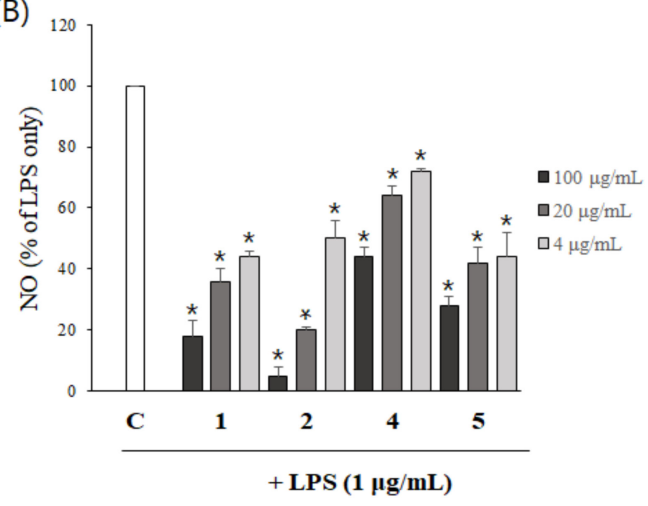

Figure 6. The inhibitory effect of the asarone derivatives on LPS-induced NO production by BV2 cells. (A) The cytotoxicity of asarone derivatives on BV2 microglial cells was determined using an MTT assay. ${ }^{\#} p<0.05$, compared to the DMSO-treated control group. (B) BV2 cells pretreated with asarone derivatives for $1 \mathrm{~h}$ were incubated with LPS for $24 \mathrm{~h}$, and the production of NO was determined using Griess reagents. Each experiment was repeated at least three times. ${ }^{*} p<0.05$, compared to the LPS only-treated group.

\section{Discussion}

Senile plaques composed of $\mathrm{A} \beta$ peptides, one of the pathologic hallmarks of $\mathrm{AD}$, are generated by proteolytic fragmentation of APPs. Many studies have implicated that A $\beta$ aggregates, rather than the monomer form, as a neurotoxic agent that leads to neurodegeneration in AD [21]. Therefore, blockade or reduction of $\mathrm{A} \beta$ aggregation is a promising therapeutic approach for $\mathrm{AD}[22,23]$.

Natural products and their active constituents have been suggested to be beneficial for treating neurodegenerative diseases including AD. For example, galantamine isolated from snowdrop has been approved by the FDA for the treatment of AD as an inhibitor of acetylcholine esterase [24,25]. Curcumin derivatives have been shown to possess a wide range of beneficial biological activities against $\mathrm{AD}$ as inhibitors of $\mathrm{A} \beta$ aggregation [26,27]. Rosmarinic acid was also reported to have neuroprotective, antioxidative, and anti-amyloidogenic properties [28]. Biflavonoids from Garcinia madruno exhibited beneficial effects in a transgenic mouse model of AD [29]. Crocin from Crocus sativus [30], and phenylpropanoids and lignans from the seeds of Prunus tomentosa [31] were shown to have anti-A $\beta$ aggregation activity. While many studies have reported an inhibitory effect of compounds derived from natural products on $A \beta$ aggregation, few have identified both anti-A $\beta$ aggregation and $A \beta$ disaggregation properties. Compounds with the capacity to inhibit $A \beta$ aggregation, as well as disaggregate preformed $A \beta$ aggregate could be an attractive candidate for development as novel therapeutic agents for $\mathrm{AD}$.

In this study, five asarone derivatives including 2,3-dimethoxy-5-(1E)-1-propen-1-yl-phenol (1), $\beta$-asarone (2), 3-(2,4,5-trimethoxyphenyl)-(2E)-2-propen-1-ol (3), asaronealdehyde (4), and $\alpha$-asarone (5) were isolated as active constituents from $P$. frutescens. To our knowledge, this is the first time 2,3-dimethoxy-5-(1E)-1-propen-1-yl-phenol (1) has been isolated from $P$. frutescens, and that 3-(2,4,5-trimethoxyphenyl)-(2E)-2-propen-1-ol (3) has been purified from a biological sample.

Asarone derivatives including $\alpha$ - and $\beta$-asarone are major bioactive phytochemicals present in the Acorus species such as Acorus calamus Linn and Acorus gramineus Solander [32,33], and Guatteria gaumeri Greenman [34]. The wide range of pharmacological activities of asarone derivatives have been reported including antiepileptic [35], antidepressant [36], anxiolytic [37], neuroprotective [38], and hypolipidemic activities [39]. Numerous clinical studies in China had reported that asarone derivatives were effective therapeutic approaches for the treatment of respiratory disorders and epilepsy $[40,41]$. Thus, it is considered to be potentially useful in the treatment of various diseases, particularly CNS disorders. On the other hand, acute and sub-chronic toxicities of $\alpha$-and $\beta$-asarone in pre-clinical toxicological studies were not detected, whereas they might cause hepatocellular 
carcinoma in chronic toxicity test due to the epoxide metabolites [42-45]. However, the extensive dose-dependent in vivo toxicological studies are required to confirm the toxicity of asarone derivatives. Therefore, the selection of dose and duration time of asarone derivatives is carefully determined to avoid the toxicity in human studies.

Among the five asarone derivatives we studied, $\beta$-asarone (2) has been reported to protect PC12 cells against A $\beta$-induced neurotoxicity [46], and improve learning and memory in APP/PS1 transgenic mice [47]; $\alpha$-Asarone (5) was reported to prevent neuroinflammation by inhibiting NF- $\kappa \mathrm{B}$ activation [48]. Nonetheless, this is the first report regarding the effect of asarone derivatives on the inhibition of $A \beta$ aggregation, the enhancement of $A \beta$ disaggregation, and the subsequent protective effects on disease-relevant cell lines.

In this study, five asarone derivatives were isolated from $P$. frutescens based on activity-guided isolation methodology using diverse column chromatography. All five asarone derivatives efficiently reduced the aggregation of $A \beta$, and furthermore, significantly increased the disaggregation of $A \beta$ aggregate. Consequently, the inhibition of $A \beta$ aggregation by asarone derivatives efficiently rescued the PC12 cells from A $\beta$ aggregate-induced toxicity. In addition, asarone derivatives significantly inhibited LPS-induced NO production by BV2 microglial cells. Taken together, these observations suggest that the asarone derivatives isolated from $P$. frutescens could exert beneficial effects against AD. Therefore, the asarone derivatives and $P$. frutescens have the potential to be developed as therapeutic or preventative drugs for AD.

\section{Materials and Methods}

\subsection{Chemicals and Reagents}

RPMI 1640 was purchased from Welgene (Daegu, Korea). Horse serum was purchased from Gibco BRL (Carlsbad, CA, USA). Fetal bovine serum (FBS) was purchased from Equitech-BIO (Kerrville, TX, USA). A $\beta_{1-42}$ was purchased from GL Biochem (Shanghai, China). A $\beta_{25-35}$ was purchased from Bachem AG (Bubendorf, Switzerland). Thioflavin T, isoproterenol and 3-(4,5-dimethyl-2-thiazolyl)-2,5-diphenyl-2H-tetrazolium bromide (MTT) was purchased from Sigma Aldrich (St. Louis, MO, USA). Dimethyl sulfoxide was purchased from Wako Pure Chemical (Mie, Japan). Acetonitrile for high performance liquid chromatography (HPLC) was purchased from Samchun (Pyeong-taek, Korea). Griess reagent was purchased from Promega Co (Madison, WI, USA).

\subsection{Plant Material}

The leaves of $P$. frutescens were purchased from a commercial market (Samhong medicinal herb market; Seoul, Korea) in 2014. A voucher specimen has been deposited in Pharmacognosy Laboratory of College of Pharmacy, Dankook University, Korea.

\subsection{Extracts and Isolation}

Dried and pulverized P. frutescens leaves $(5 \mathrm{~kg})$ were extracted with $90 \%$ of methanol $(\mathrm{MeOH}$, $40 \mathrm{~L}, 3$ times) at room temperature. The $\mathrm{MeOH}$ filtrate was evaporated under vacuum to yield the $\mathrm{MeOH}$ extract (308 g). The extract was suspended in distilled water and then partitioned sequentially into $n$-hexane (111.5 g), dichloromethane (5.6 g), ethyl acetate (16.9 g) and water (119 g). Each layer was dissolved in dimethyl sulfoxide (DMSO) for the bioassay.

The $n$-hexane fraction was dried and further fractionated on silica-gel column chromatography with a solvent mixture of $n$-hexane: ethyl acetate $(20: 1,10: 1,5: 1,1: 1 ; 2 \mathrm{~L}$ of each solvent mixture) and seven fractions were obtained (PFH1 PFH 7). Two g of fraction PF3 was chromatographed on a medium pressure liquid chromatography (MPLC, Isolera One, Biotage, Korea) using 50\% $\mathrm{MeOH}$ isocratic and five fractions were obtained (PFH3-1-PFH3-5). Among five subfractions, PFH3-3 was further chromatographed on a MPLC with same condition, and the subfraction PFH3-3-4 was obtained as a pure compound (compound 1, 2,3-dimethoxy-5-(1E)-1-propen-1-yl-phenol, $22.7 \mathrm{mg}$ ). Subfraction PFH3-3-6 
was further purified with semi-preparative HPLC (YMC-Pack ODS-A, $250 \times 10 \mathrm{~mm}, 5 \mu \mathrm{m}$ ) using 40\% acetonitrile isocratic elution system and compound 2 ( $\beta$-asarone, $1.0 \mathrm{mg}$ ) was obtained. The fraction PFH3-3-2 was purified with semi-preparative HPLC using 20\%-100\% acetonitrile, compound 3 (3-(2,4,5-trimethoxyphenyl)-(2E)-2-propen-1-ol, $0.9 \mathrm{mg}$ ) and compound 4 (asaronealdehyde, $6.6 \mathrm{mg}$ ) were obtained. The fraction PFH3-5 was obtained as a pure compound (compound 5, $\alpha$-asarone, $200 \mathrm{mg})$.

The purified compounds were subjected to nuclear magnetic resonance (NMR). ${ }^{1} \mathrm{H}(700 \mathrm{MHz})$ and ${ }^{13} \mathrm{C}$ NMR (177 MHz) were investigated with a NMR spectrometer (AdvanceIII, Bruker, Germany).

2,3-Dimethoxy-5-[(1E)-1-propen-1-yl]-phenol (1) $\mathrm{C}_{11} \mathrm{H}_{14} \mathrm{O}_{3} \mathrm{MS} m / z 195[\mathrm{M}+\mathrm{H}]^{+} .{ }^{1} \mathrm{H} \mathrm{NMR}\left(\mathrm{CD}_{3} \mathrm{OD}\right)$ $\delta: 6.50(1 \mathrm{H}, \mathrm{d}, J=0.7 \mathrm{~Hz}, \mathrm{H}-4), 6.50(1 \mathrm{H}, \mathrm{d}, J=0.7 \mathrm{~Hz}, \mathrm{H}-6), 6.27(1 \mathrm{H}, \mathrm{dd}, J=1.4,15.4 \mathrm{~Hz}, \mathrm{H}-7), 6.14$ $(1 \mathrm{H}, \mathrm{dq}, J=7.0,15.8 \mathrm{~Hz}, \mathrm{H}-8), 1.85$ (3H, dd, $J=1.4,6.7 \mathrm{~Hz}, \mathrm{H}-9), 3.78(3 \mathrm{H}, \mathrm{s}, \mathrm{H}-10), 3.83(3 \mathrm{H}, \mathrm{s}, \mathrm{H}-11)$. ${ }^{13} \mathrm{C}-\mathrm{NMR}\left(\mathrm{CD}_{3} \mathrm{OD}\right) \mathrm{\delta}: 150.1$ (C-1), 135.5 (C-2), 153.1 (C-3), 101.3 (C-4), 134.1 (C-5), 106.3 (C-6), 130.8 (C-7), 124.1 (C-8), 17.1 (C-9), 54.9 (C-10), 59.6 (C-11). $\log \mathrm{P}(\mathrm{o} / \mathrm{w}): 2.370$ (est).

$\beta$-asarone (2) $\mathrm{C}_{12} \mathrm{H}_{16} \mathrm{O}_{3} \mathrm{MS} m / z 209[\mathrm{M}+\mathrm{H}]^{+} .{ }^{1} \mathrm{H} \mathrm{NMR}\left(\mathrm{CD}_{3} \mathrm{OD}\right) \delta: 6.68(1 \mathrm{H}, \mathrm{s}, \mathrm{H}-3), 6.88(1 \mathrm{H}, \mathrm{s}$, H-6), $6.44(1 \mathrm{H}, \mathrm{dq}, J=2.1,11.6 \mathrm{~Hz}, \mathrm{H}-7), 5.71(1 \mathrm{H}, \mathrm{dq}, J=7.0,11.9 \mathrm{~Hz}, \mathrm{H}-8), 1.83(3 \mathrm{H}, \mathrm{dd}, J=2.1,7.0 \mathrm{~Hz}$,

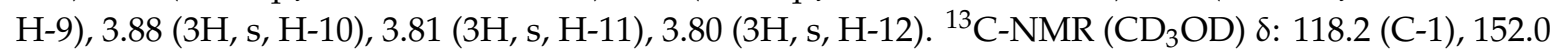
(C-2), 97.9 (C-3), 149.0 (C-4), 142.3 (C-5), 114.9 (C-6), 124.7 (C-7), 124.6 (C-8), 13.5 (C-9), 56.2 (C-10), 55.4 (C-11), $55.3(\mathrm{C}-12) \cdot \log \mathrm{P}(\mathrm{o} / \mathrm{w}): 3.406$ (est).

3-(2,4,5-trimethoxyphenyl)-(2E)-2-Propen-1-ol (3) $\mathrm{C}_{12} \mathrm{H}_{16} \mathrm{O}_{3} \mathrm{MS} m / z 225[\mathrm{M}+\mathrm{H}]^{+}$. ${ }^{1} \mathrm{H} \mathrm{NMR}\left(\mathrm{CD} \mathrm{OD}_{3}\right)$ $\delta: 6.66(1 \mathrm{H}, \mathrm{s}, \mathrm{H}-3), 7.08(1 \mathrm{H}, \mathrm{s}, \mathrm{H}-6), 6.85(1 \mathrm{H}, \mathrm{dt}, J=1.4,16.1 \mathrm{~Hz}, \mathrm{H}-7), 6.25(1 \mathrm{H}, \mathrm{dt}, J=6.3,16.1$ $\mathrm{Hz}, \mathrm{H}-8), 4.22$ (2H, dd, $J=1.4,6.3 \mathrm{~Hz}, \mathrm{H}-9), 3.88$ (3H, s, H-10), 3.84 (3H, s, H-11), 3.82 (3H, s, H-12). ${ }^{13} \mathrm{C}-\mathrm{NMR}\left(\mathrm{CD}_{3} \mathrm{OD}\right)$ 8: 117.7 (C-1), 153.1 (C-2), 97.4 (C-3), 150.3 (C-4), 144.1 (C-5), 110.7 (C-6), 125.8 (C-7), 128.6 (C-8), 62.9 (C-9), 56.0 (C-10), 55.6 (C-11), 55.2 (C-12). $\log \mathrm{P}$ (o/w): 1.290 (est).

asaronealdehyde (4) $\mathrm{C}_{10} \mathrm{H}_{12} \mathrm{O}_{4} \mathrm{MS} m / z 197[\mathrm{M}+\mathrm{H}]^{+} .{ }^{1} \mathrm{H} \mathrm{NMR}\left(\mathrm{CD}_{3} \mathrm{OD}\right) \delta: 6.73(1 \mathrm{H}, \mathrm{s}, \mathrm{H}-3), 7.28$ (1H, s, H-6), 10.2 (1H, s, H-7), 3.97 (3H, s, H-8), 3.96 (3H, s, H-9), $3.82(3 \mathrm{H}, \mathrm{s}, \mathrm{H}-10) .{ }^{13} \mathrm{C}-\mathrm{NMR}\left(\mathrm{CD}{ }_{3} \mathrm{OD}\right)$

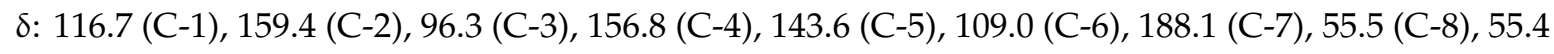
(C-10), $55.4(\mathrm{C}-11) \cdot \log \mathrm{P}(\mathrm{o} / \mathrm{w}): 1.634$ (est).

$\alpha$-asarone (5) $\mathrm{C}_{12} \mathrm{H}_{16} \mathrm{O}_{3} \mathrm{MS} m / z 209[\mathrm{M}+\mathrm{H}]^{+} .{ }^{1} \mathrm{H}$ NMR $\left(\mathrm{CD}_{3} \mathrm{OD}\right) \delta: 6.62(1 \mathrm{H}, \mathrm{s}, \mathrm{H}-3), 7.01(1 \mathrm{H}, \mathrm{s}$, H-6), $6.11(1 \mathrm{H}, \mathrm{dq}, J=2.1,14.0 \mathrm{~Hz}, \mathrm{H}-7), 4.89(1 \mathrm{H}, \mathrm{dq}, J=6.3,15.4 \mathrm{~Hz}, \mathrm{H}-8), 1.86(3 \mathrm{H}, \mathrm{dd}, J=2.1,6.7 \mathrm{~Hz}$, H-9), 3.85 (3H, s, H-10), 3.81 (3H, s, H-11), 3.80 (3H, s, H-12). ${ }^{13}$ C-NMR (CD $\left.{ }_{3} \mathrm{OD}\right) \delta: 119.0$ (C-1), 151.1 (C-2), 98.1 (C-3), 149.0 (C-4), 143.2 (C-5), 110.5 (C-6), 125.0 (C-7), 123.1 (C-8), 17.5 (C-9), 56.0 (C-10), 55.6 (C-11), $55.2(\mathrm{C}-12) . \log \mathrm{P}(\mathrm{o} / \mathrm{w}): 2.794(\mathrm{est})$.

\subsection{Thioflavin $\mathrm{T}(\mathrm{ThT})$ Assay}

To evaluate the aggregate formation of $A \beta$, a ThT assay was performed [15]. The $A \beta_{1-42}$ was dissolved in DMSO at $1 \mathrm{mg} / \mathrm{mL}$ concentration and five asarone derivatives were diluted in DMSO. To monitor the effects of asarone derivatives on the aggregate of $\mathrm{A} \beta, 20 \mu \mathrm{M}$ of $\mathrm{A} \beta_{1-42}$ was incubated together with various concentrations $(4,20$, and $100 \mu \mathrm{g} / \mathrm{mL})$ of asarone derivatives at $37^{\circ} \mathrm{C}$ for $24 \mathrm{~h}$. Then, $3 \mu \mathrm{M}$ of ThT was added (protected from light) and fluorescence was measured after $30 \mathrm{~min}$ using an Emax precision microplate reader (black plate) (Molecular Devices, CA, USA) with excitation at $442 \mathrm{~nm}$ and emission at $485 \mathrm{~nm}$. The A $\beta$ treated with DMSO was used as a control and each assay was performed in triplicate.

To monitor the disaggregation effects of asarone derivatives on pre-aggregated $\mathrm{A} \beta$, a ThT assay was performed. Briefly, $20 \mu \mathrm{M}$ of $\mathrm{A} \beta_{1-42}$ was incubated at $37^{\circ} \mathrm{C}$ for $24 \mathrm{~h}$. Various concentrations (4, 20 , and $100 \mu \mathrm{g} / \mathrm{mL}$ ) of asarone derivatives were then added for an additional incubation at $37^{\circ} \mathrm{C}$ for additional $24 \mathrm{~h}$ (protected from light). Then, $3 \mu \mathrm{M}$ of ThT was added and fluorescence was measured after 30 min using an Emax precision microplate reader (black plate) with excitation at $442 \mathrm{~nm}$ and emission at $485 \mathrm{~nm}$. A $\beta$ only-treated group was used as a control and each assay was performed in triplicate. 


\subsection{Cell Viabiltiy Assay}

PC12 cells (rat pheochromocytoma cells) were obtained from Korea Cell Line Bank (Seoul, Korea) and grown in RPMI 1640 medium supplemented with 5\% heat-inactivated FBS and 15\% heat-inactivated horse serum. The cells were incubated in a humidified $5 \% \mathrm{CO}_{2}$ atmosphere at $37^{\circ} \mathrm{C}$. The cells growing exponentially were harvested from flasks and plated in 96-well plates with approximately $6 \times 10^{4}$ cells per $100 \mu \mathrm{L}$ of medium per well. Plates were incubated at $37^{\circ} \mathrm{C}$ for $3 \mathrm{~h}$ to allow the cells to attach to the plates.

In order to determine the possible cytotoxicity of asarone derivatives themselves, compounds were added to individual wells $(4,20$, and $100 \mu \mathrm{g} / \mathrm{mL})$. The plates were then incubated for $24 \mathrm{~h}$ at $37^{\circ} \mathrm{C}$. Cell viability was determined using a MTT toxicity assay by adding $10 \mu \mathrm{L}$ of $5 \mathrm{mg} / \mathrm{mL}$ MTT to each well. After $3 \mathrm{~h}$ of incubation at $37^{\circ} \mathrm{C}, 100 \mu \mathrm{L}$ of DMSO was added to each well. Plates were incubated at room temperature for $30 \mathrm{~min}$ to dissolve the MTT formazan crystals and the absorbance at $570 \mathrm{~nm}$ was measured using a Emax precision microplate reader. Averages from three replicate wells were used for each sample and each assay was performed in triplicate.

In order to determine the protective effect of asarone derivatives against $A \beta$, the cells in 96-well plates were pre-treated with asarone derivatives $(4,20$, and $100 \mu \mathrm{g} / \mathrm{mL})$ for $1 \mathrm{~h}$ and then followed by the treatment with $A \beta\left(A \beta_{25-35}, 10 \mu \mathrm{M}\right)$. The plates were then incubated for an additional $24 \mathrm{~h}$ at $37^{\circ} \mathrm{C}$. Cell viability was determined using a MTT toxicity assay. Averages from three replicate wells were used for each sample and each assay was performed in triplicate.

To investigate whether the inhibition of $A \beta$ aggregation by asarone derivatives affects the viability of PC12 cells against $A \beta$ aggregate-induced toxicity, compounds $(4,20$, and $100 \mu \mathrm{g} / \mathrm{mL})$ and $A \beta_{1-42}$ $(10 \mu \mathrm{M})$ were mixed together in 96 -well plates and incubated at $37^{\circ} \mathrm{C}$ for $24 \mathrm{~h}$ to inhibit the formation of $\mathrm{A} \beta$ aggregates. Then, the mixture was added to the cells in 96 -well plates and incubated at $37^{\circ} \mathrm{C}$ for an additional $24 \mathrm{~h}$. Cell viability was determined using a MTT toxicity assay. Averages from three replicate wells were used for each sample and each assay was performed in triplicate.

\subsection{Determination of NO production}

BV2 cells (immortalized mouse microglial cells) were grown in a DMEM medium supplemented with $5 \%$ heat-inactivated FBS. The cells were incubated in a humidified $5 \% \mathrm{CO}_{2}$ atmosphere at $37^{\circ} \mathrm{C}$. BV2 cells growing exponentially were harvested from flasks and plated in 96-well plates with approximately $6 \times 10^{4}$ cells per $100 \mu \mathrm{L}$ of medium per well. Plates were incubated at $37^{\circ} \mathrm{C}$ for $3 \mathrm{~h}$ to allow the cells to attach to the plates. Compounds $(4,20$, and $100 \mu \mathrm{g} / \mathrm{mL})$ were added to individual wells. After $1 \mathrm{~h}$, LPS was added in each culture well with $1 \mu \mathrm{g} / \mathrm{mL}$ of concentration. The plates were then incubated for an additional $24 \mathrm{~h}$ at $37^{\circ} \mathrm{C}$. The NO production was determined using Griess reagents [49]. The supernatant was mixed with an equal volume of the sulfanilamide solution and incubated at $37^{\circ} \mathrm{C}$ for $10 \mathrm{~min}$ in the dark. Then the NED solution was added with same volume and incubated for 10 more min in the dark. The absorbance at $540 \mathrm{~nm}$ was measured using a Emax precision microplate reader. Averages from three replicate wells were used for each sample and each assay was performed in triplicate.

\subsection{Statistical Analyses}

All data in the text and figures are expressed as means $\pm \mathrm{SD}$. Two or more group comparisons were evaluated by one-way analysis of variance followed by Tukey post hoc text (SPSS version 17.0, Armonk, NY, USA). Differences were considered statistically significant at $p<0.05$.

Supplementary Materials: The following are available online at http://www.mdpi.com/1420-3049/24/23/4297/s1, Figure S1: Direct effect of asarone derivatives on Th T fluorescence, Figure S2: The effect of asarone derivatives on $\mathrm{A} \beta$ aggregation determined by western blot analysis. 
Author Contributions: S.-Y.P. conceived and designed the experiments; J.E.L., D.-G.S., J.-S.L. and N.K. performed the experiments; J.E.L., D.-G.S., J.-S.L., S.K. and J.Y.Y. analyzed the data and K.W.H. contributed to manuscript structure and flow; J.E.L. and N.K. wrote the paper; S.-Y.P., K.W.H., and S.K. revised the manuscript. All authors reviewed and confirmed the manuscript.

Funding: This research was supported by Korea Institute of Planning and Evaluation for Technology in Food, Agriculture, Forestry and Fisheries (IPET) through High Value-Added Food Technology Development Program, funded by Ministry of Agriculture, Food and Rural Affairs (MAFRA, Republic of Korea) (119012031HD020), and National Research Foundation of Korea (NRF-2013-0003980).

Conflicts of Interest: The authors have no conflicts of interest to declare.

\section{References}

1. Hardy, J.A.; Higgins, G.A. Alzheimer's disease: the amyloid cascade hypothesis. Science 1992, $256,184$. [CrossRef]

2. Mudher, A.; Lovestone, S. Alzheimer's disease-do tauists and baptists finally shake hands? Trends Neurosci. 2002, 25, 22-26. [CrossRef]

3. Hardy, J.; Selkoe, D.J. The amyloid hypothesis of Alzheimer's disease: progress and problems on the road to therapeutics. Science 2002, 297, 353-356. [CrossRef]

4. Olsson, F.; Schmidt, S.; Althoff, V.; Munter, L.M.; Jin, S.; Rosqvist, S.; Lundkvist, J. Characterization of Intermediate Steps in Amyloid Beta (A $\beta$ ) Production under Near-native Conditions. J. Bio. Chem. 2014, 289, 1540-1550. [CrossRef]

5. Yang, S.G.; Wang, W.Y.; Ling, T.J.; Feng, Y.; Du, X.T.; Zhang, X.; Liu, R.T. Alpha-tocopherol quinone inhibits beta-amyloid aggregation and cytotoxicity, disaggregates preformed fibrils and decreases the production of reactive oxygen species, NO and inflammatory cytokines. Neurochem. Int. 2010, 57, 914-922. [CrossRef] [PubMed]

6. Heneka, M.T.; O’Banion, M.K. Inflammatory processes in Alzheimer's disease. J. Neuroimmunol. 2007, 184, 69-91. [CrossRef] [PubMed]

7. Ahmed, H.M. Ethnomedicinal, Phytochemical and Pharmacological Investigations of Perilla Frutescens (L.) Britt. Molecules 2018, 24, 102. [CrossRef] [PubMed]

8. Lim, H.J.; Woo, K.W.; Lee, K.R.; Lee, S.K.; Kim, H.P. Inhibition of proinflammatory cytokine generation in lung inflammation by the leaves of Perilla frutescens and its constituents. Biomol. Ther. 2014, 22, 62. [CrossRef] [PubMed]

9. Makino, T.; Furuta, Y.; Wakushima, H.; Fujii, H.; Saito, K.I.; Kano, Y. Anti-allergic effect of Perilla frutescens and its active constituents. Phytoth. Res. 2003, 17, 240-243. [CrossRef]

10. Osakabe, N.; Yasuda, A.; Natsume, M.; Yoshikawa, T. Rosmarinic acid inhibits epidermal inflammatory responses: anticarcinogenic effect of Perilla frutescens extract in the murine two-stage skin model. Carcinogenesis 2004, 25, 549-557. [CrossRef]

11. Ueda, H.; Yamazaki, C.; Yamazaki, M. Luteolin as an anti-inflammatory and anti-allergic constituent of Perilla frutescens. Biol. Pharm. Bull. 2002, 25, 1197-1202. [CrossRef] [PubMed]

12. Ueda, H.; Yamazaki, C.; Yamazaki, M. Inhibitory effect of Perilla leaf extract and luteolin on mouse skin tumor promotion. Biol. Pharm. Bull. 2003, 26, 560-563. [CrossRef] [PubMed]

13. Nakazawa, T.; Yasuda, T.; Ueda, J.; Ohsawa, K. Antidepressant-like effects of apigenin and 2, 4, 5-trimethoxycinnamic acid from Perilla frutescens in the forced swimming test. Biol. Pharm. Bull. 2003, 26, 474-480. [CrossRef] [PubMed]

14. Choi, S.H.; Hur, J.M.; Yang, E.J.; Jun, M.; Park, H.J.; Lee, K.B.; Song, K.S. $\beta$-Secretase (BACE1) inhibitors from Perilla frutescens var. acuta. Arch. Pharm. Rer. 2008, 31, 183-187. [CrossRef] [PubMed]

15. Kim, D.J.; Kim, M.S.; Kim, S.; Hwang, K.W.; Park, S.Y. Anti-amyloidogenic effects of Perilla frutescens var. acutaon beta-amyloid aggregation and disaggregation. J. Food Biochem. 2017, 41, e12393. [CrossRef]

16. Sairafianpour, M.; Kayser, O.; Christensen, J.; Asfa, M.; Witt, M.; Stærk, D.; Jaroszewski, J.W. Leishmanicidal and Antiplasmodial Activity of Constituents of Smirnowia i ranica. J. Nat. Prod. 2002, 65, 1754-1758. [CrossRef]

17. Lee, J.Y.; Lee, J.Y.; Yun, B.S.; Hwang, B.K. Antifungal activity of $\beta$-asarone from rhizomes of Acorus gramineus. J. Agr. Food Chem. 2004, 52, 776-780. [CrossRef] 
18. Cartus, A.T.; Stegmuller, S.; Simson, N.; Wahl, A.; Neef, S.; Kelm, H.; Schrenk, D. Hepatic Metabolism of Carcinogenic $\beta$-asarone. Chem. Res. Toxicol. 2015, 28, 1760-1773. [CrossRef]

19. Czepa, A.; Hofmann, T. Structural and sensory characterization of compounds contributing to the bitter off-taste of carrots (Daucus carota L.) and carrot puree. J. Agr. Food Chem. 2003, 51, 3865-3873. [CrossRef]

20. Siergiejczyk, L.; Poplawski, J.; Lozowicka, B.; Dubis, A.; Lachowska, B. 1H and 13C NMR spectral analysis of (E)-asarone and its isomers. Mag. Reson. Chem. 2000, 38, 1037-1038. [CrossRef]

21. Kirkitadze, M.D.; Bitan, G.; Teplow, D.B. Paradigm shifts in Alzheimer's disease and other neurodegenerative disorders: The emerging role of oligomeric assemblies. J. Neurosci. Res. 2002, 69, 567-577. [CrossRef] [PubMed]

22. Mullan, M.; Crawford, F.; Axelman, K.; Houlden, H.; Lilius, L.; Winblad, B.; Lannfelt, L. A pathogenic mutation for probable Alzheimer's disease in the APP gene at the N-terminus of $\beta$-amyloid. Nat. Genet. 1992, 1, 345-347. [CrossRef] [PubMed]

23. Sisodia, S.S.; Koo, E.H.; Beyreuther, K.; Unterbeck, A.; Price, D.L. Evidence that beta-amyloid protein in Alzheimer's disease is not derived by normal processing. Science 1990, 248, 492-495. [CrossRef] [PubMed]

24. Kumar, N.S.; Nisha, N. Phytomedicines as potential inhibitors of $\beta$ amyloid aggregation: significance to Alzheimer's disease. Chin. J. Nat. Med. 2014, 12, 801-818. [CrossRef]

25. Ingkaninan, K.; Temkitthawon, P.; Chuenchom, K.; Yuyaem, T.; Thongnoi, W. Screening for acetylcholinesterase inhibitory activity in plants used in Thai traditional rejuvenating and neurotonic remedies. J. Ethnopharmacol. 2003, 89, 261-264. [CrossRef] [PubMed]

26. Giacomeli, R.; Izoton, J.C.; Dos Santos, R.B.; Boeira, S.P.; Jesse, C.R.; Haas, S.E. Neuroprotective effects of curcuminlipid-core nanocapsules in a model Alzheimer's disease induced by $\beta$-amyloid 1-42 peptide in aged female mice. Brain Res. 2019, 1721, 146325. [CrossRef] [PubMed]

27. Bukhari, S.N. Synthetic Curcumin Analogs as Inhibitors of $\beta$-Amyloid Peptide Aggregation: Potential Therapeutic and Diagnostic Agents for Alzheimer's Disease. Mini. Rev. Med. Chem. 2015, 15, 1110-1121. [CrossRef]

28. Rong, H.; Liang, Y.; Niu, Y. Rosmarinic acid attenuates $\beta$-amyloid-induced oxidative stress via Akt/GSK-3ß/Fyn-mediated Nrf2 activation in PC12 cells. Free Radic. Biol. Med. 2018, 120, 114-123. [CrossRef]

29. Sabogal-Guáqueta, A.M.; Carrillo-Hormaza, L.; Osorio, E.; Cardona-Gómez, G.P. Effects of biflavonoids from Garcinia madruno on a triple transgenic mouse model of Alzheimer's disease. Pharmacol. Res. 2018, 129, 128-138. [CrossRef]

30. Papandreou, M.A.; Kanakis, C.D.; Polissiou, M.G.; Efthimiopoulos, S.; Cordopatis, P.; Margarity, M.; Lamari, F.N. Inhibitory activity on amyloid- $\beta$ aggregation and antioxidant properties of Crocus sativus stigmas extract and its crocin constituents. J. Agr. Food Chem. 2006, 53, 8762-8768. [CrossRef]

31. Liu, Q.; Wang, J.; Lin, B.; Cheng, Z.Y.; Bai, M.; Shi, S.; Huang, X.X.; Song, S.J. Phenylpropanoids and lignans from Prunus tomentosa seeds as efficient $\beta$-amyloid (A $\beta$ ) aggregationinhibitors. Bioorg. Chem. 2019, 84, 269-275. [CrossRef] [PubMed]

32. Zou, D.J.; Wang, G.; Liu, J.C.; Dong, M.X.; Li, X.M.; Zhang, C.; Zhou, L.; Wang, R.; Niu, Y.C. Beta-asarone attenuates beta-amyloid-induced apoptosis through the inhibition of the activation of apoptosis signal-regulating kinase 1 in SH-SY5Y cells. Die Pharm. Int. J. Pharm. Sci. 2011, 66, 44-51.

33. Park, C.H.; Kim, K.H.; Lee, I.K.; Lee, S.Y.; Choi, S.U.; Lee, J.H.; Lee, K.R. Phenolic constituents of Acorus gramineus. Arch. Pharm. Res. 2011, 34, 1289-1296. [CrossRef] [PubMed]

34. Chamorro, G.; Salazar, M.; Tamariz, J.; Labarrios, F. Dominant lethal study of alpha-asarone in male and female mice after sub-chronic treatment. Phytother 1999. [CrossRef]

35. Bhat, S.D.; Ashok, B.K.; Acharya, R.N.; Ravishankar, B. Anticonvulsant activity of raw and classically processed Vacha (Acorus calamus Linn.) rhizomes. Ayu 2012, 33, 119-122. [CrossRef]

36. Chellian, R.; Pandy, V.; Mohamed, Z. Biphasic Effects of $\alpha$-Asarone on Immobility in the Tail Suspension Test: Evidence for the Involvement of the Noradrenergic and Serotonergic Systems in Its Antidepressant-Like Activity. Front. Pharmacol. 2016, 7, 72. [CrossRef]

37. Lee, B.; Sur, B.; Yeom, M.; Shim, I.; Lee, H.; Hahm, D.H. Alpha-Asarone, a Major Component of Acorus gramineus, Attenuates Corticosterone-Induced Anxiety-Like Behaviours via Modulating TrkB Signaling Process. Korean J. Physiol. Pharmacol. 2014, 18, 191-200. [CrossRef] 
38. An, H.M.; Li, G.W.; Lin, C.; Gu, C.; Jin, M.; Sun, W.X.; Qiu, M.F.; Hu, B. Acorus tatarinowii Schott extract protects PC12 cells from amyloid-beta induced neurotoxicity. Die Pharm. Int. J. Pharm. Sci. 2014, 69, 391-395.

39. Mdina-Franco, J.L.; Lopez-Vallejo, F.; Rodriguez-Morales, S.; Castillo, R.; Chamorro, G.; Tamariz, J. Molecular docking of the highly hypolipidemic agent alpha-asarone with catalytic portion of HMG-CoA reductase. Bioorg. Med. Chem. Lett. 2005, 15, 989-994. [CrossRef]

40. Feng, X.-L.; Yu, Y.; Qin, D.-P.; Gao, H.; Yao, X.-S. Acorus Linnaeus: A review of traditional uses, phytochemistry and neuropharmacology. RSC Adv. 2015, 5, 5173-5182. [CrossRef]

41. Zhang, Q.; Ma, W.C.; Li, H.; Mao, S.J. Asarone injection in treating respiratory disease: A meta-analysis. Chin. J. Evid. -Based Med. 2010, 10, 1174-1181.

42. Liu, L.; Wang, J.; Shi, L.; Zhang, W.; Du, X.; Wang, Z.; Zhang, Y. beta-Asarone induces senescence in colorectal cancer cells by inducing lamin B1 expression. Phytomedicine 2013, 20, 512-520. [CrossRef] [PubMed]

43. Wiseman, R.W.; Miller, E.C.; Miller, J.A.; Liem, A. Structure-activity studies of the hepatocarcinogenicities of alkenylbenzene derivatives related to estragole and safrole on administration to preweanling male C58BL/6 x C3H/He J F1 mice. Cancer Res. 1987, 47, 2275-2283. [PubMed]

44. Chen, Q.X.; Miao, J.K.; Li, C.; Li, X.W.; Wu, X.M.; Zhang, X.P. Anticonvulsant activitiy of acute and chronic treatment with a-asarone from Acorus gramineus in seizure models. Biol. Pharm. Bull. 2013, 36, 23-30. [CrossRef]

45. Chellian, R.; Pandy, V.; Mohamed, Z. Pharmacology and toxicology of $\alpha$ - and $\beta$-Asarone: A review of preclinical evidence. Phytomedicin 2017, 32, 41-58. [CrossRef]

46. Li, C.; Xing, G.; Dong, M.; Zhou, L.; Li, J.; Wang, G.; Niu, Y. Beta-asarone protection against beta-amyloid-induced neurotoxicity in PC12 cells via JNK signaling and modulation of Bcl-2 family proteins. Eur. J. Pharmacol. 2010, 635, 96-102. [CrossRef]

47. Deng, M.; Huang, L.; Ning, B.; Wang, N.; Zhang, Q.; Zhu, C.; Fang, Y. $\beta$-asarone improves learning and memory and reduces Acetyl Cholinesterase and Beta-amyloid42 levels in APP/PS1 transgenic mice by regulating Beclin-1-dependent autophagy. Brain Res. 2016, 1652, 188-194. [CrossRef]

48. Kim, B.W.; Koppula, S.; Kumar, H.; Park, J.Y.; Kim, I.W.; More, S.V.; Choi, D.K. $\alpha$-Asarone attenuates microglia-mediated neuroinflammation by inhibiting NF kappa B activation and mitigates MPTP-induced behavioral deficits in a mouse model of Parkinson's disease. Neuropharmacology 2015, 97, 46-57. [CrossRef]

49. Lee, S.R.; Kim, M.S.; Kim, S.; Hwang, K.W.; Park, S.Y. Constituents from Scutellaria barbata Inhibiting Nitric OxideProduction in LPS-Stimulated Microglial Cells. Chem. Biodivers. 2017, 14, e1700231. [CrossRef]

Sample Availability: Samples of the compounds $\mathbf{2}$ and $\mathbf{5}$ are available from the authors.

(C) 2019 by the authors. Licensee MDPI, Basel, Switzerland. This article is an open access article distributed under the terms and conditions of the Creative Commons Attribution (CC BY) license (http://creativecommons.org/licenses/by/4.0/). 